\title{
RASA KEHILANGAN DALAM PUISI PESONA BUNGA YANG SIRNA KARYA ERICK HIDAYAT; KAJIAN PSIKOANALISIS LACAN
}

\author{
Rahmat Sulhan Hardi \\ Program Studi Pendidikan Bahasa dan Sastra Indonesia \\ FKIP Universitas Muhammadiyah Mataram \\ soelhanhr@yahoo.co.id
}

\begin{abstract}
ABSTRAK
Objek material penelitian ini adalah puisi yang berjudul "Pesona Bunga yang Sirna" karya Erick Hidayat. Penelitian ini bertujuan untuk mendeskripsikan perasaan pengarang dengan mengkajinya menggunakan psikoanalisis Lacan. Hasil yang diperolah adalah bahwa dalam puisi tergambarkan perasaan pengarang dengan hasrat yang tidak pernah terpenuhi. Memang, satu waktu hasrat itu terpenuhi, akan tetapi itu tidaklah lama. Itu adalah keterpenuhan yang menipu. Ia kemudian berubah menjadi rasa kekurangan dan kehilangan yang baru. Puisi ini secara tidak langsung menggambarkan hasrat manusia yang takkan pernah terpenuhi. Subjek dalam puisi ini untuk sementara, merasa dirinya terpenuhi dengan hadirnya seorang kekasih. Akan tetapi, seiring berjalannya waktu ternyata subjek menyadari bahwa kekasih yang dianggapnya mampu memenuhi dan mengisi apa yang hilang dari dirinya itu tidak dapat terpenuhi. Subjek merasakan kembali rasa kehilangan dan ketidakutuhan. Apa yang disebut keterpenuhan diri tadi tidaklah pernah bertahan lama dan akan selalu berubah menjadi kehilangan lain atau kekurangan lain lagi yang menuntut untuk dipenuhi. Begitu seterusnya. Dengan demikian, pemenuhan akan hasrat secara sempurna adalah hal yang ideal dan yang tak mungkin dapat diraih.
\end{abstract}

Kata kunci: puisi, kehilangan, psikoanalisis Lacan.

\section{PENDAHULUAN}

Puisi merupakan karya sastra yang paling berpotensi menjadi sarana paling mudah untuk mencurahkan perasaan. Dapat dikatakan pula, puisi menjadi sarana paling popular dalam hal memotret perasaan manusia, khususnya dalam masalah kehilangan, kegelisahan, termasuk juga pengalaman hidup manusia dibandingkan dua jenis karya sastra lain, prosa dan drama.

$\begin{array}{llr}\text { Dalam } & \text { hal } & \text { pengalaman } \\ \text { perkembangan } & \text { manusia, } & \text { Lacan } \\ \text { berpendapat bahwa ada tiga tahap }\end{array}$

pengalaman perkembangan manusia yang dikenal dengan tripartite model: yang nyata (the Real), yang imajiner (the Imaginary), dan tahap simbolik (the symbolic). Lintasan fase-fase tersebut oleh Lacan dipertemukan dengan konsep kebutuhan (need), permintaan (demand), dan hasrat (desire).

Kebutuhan (need) secara sederhana dapat diartikan sebagai kebutuhan secara fisiologis. Pada bayi manusia, kebutuhankebutuhan fisiologis, melalui peran orangorang terdekat terutama ibu yang. saat lapar bayi memperoleh ASI, ketika 
membutuhkan kehangatan bayi mendapat pelukan, dan lain-lain. Artinya bayi selalu merasakan sesuatu yang penuh, utuh atau tanpa kekurangan, kehilangan dan kekosongan. Pada fase ini bayi belum mengenal bahasa dan belum dapat membedakan antara diri dengan "liyan" (yang lain): bayi masih merasakan bahwa dirinya dan seluruh yang liyan merupakan satu kesatuan. Fase kebutuhan (need) ini berdiam dalam "Yang Nyata" yang merupakan "fase sebelum pikiran".

$$
\text { Ketika bayi mulai dapat }
$$
membedakan dirinya dengan yang selain dirinya meskipun pada fase awal ini bayi tetaplah belum memiliki konsep tentang "liyan" secara utuh; bayi belum memiliki kemampuan membedakan secara biner antara diri dan liyan, bayi mulai memasuki tahapan baru, yakni permintaan (demand). Permintaan adalah sesuatu yang tidak dapat atau tidak mungkin terpenuhi. Itulah esensi utama dari permintaan; kembali pada keutuhan. Hal tersebut tentulah mustahil, karena perlahan keliyanan semakin menunjukkan diri di hadapan sang bayi. Bayi akhirnya memulai fase "Yang Imajiner".

Dalam Yang Imajiner terjadi fase cermin. Bayi suatu ketika akan menyaksikan bayangan dirinya dalam cermin. Bayangan tersebut, oleh bayi, dikonfrontir dengan keberadaan yang lain seperti ibu atau pengasuh lainnya. Bayi akan melihat citra dalam cermin kemudian melihat ke arah yang lain. Saat itulah bayi mulai menyadari bahwa dirinya adalah eksis dan terpisah dari yang lain, bahkan ibu. Itulah Individuasi. Tapi bayi mengira dirinya yang berada dalam cermin adalah benar-benar dirinya. Citra tersebutlah yang akhirnya diakui sebagai "aku" atau ego. Jadi, ego terbentuk dari kesalahan mempersepsi citra cerminal sebagai aku. Citra tersebut dalam bahasa psikoanalisa disebut sebagai ego ideal. Sebagai citra cerminal, ego ideal tidak akan pernah cocok dengan keadaan individu yang sebenarnya.

Ketika bayi semakin dapat melakukan pembedaan dan proyeksi ideide tentang keliyanan, tataran Yang Simbolik dimulai. Bersamaan dengan itu terjadilah akuisisi bahasa. Yang Simbolik adalah keberadaan "aku" dalam struktur bahasa. Keadaan di mana aku dinyatakan melalui bahasa. Hanya saja keberadaan antara "Yang Imajiner" dan "Yang Simbolik" tidak memiliki batas yang jelas. Keduanya saling tumpang tindih. Di dalam tataran inilah hasrat (desire) berdiam.

Teori Lacan mengenai subjek menyerupai cerita klasik. Ia bermula dari kelahiran dan kemudian bergerak melalui teritorialisasi tubuh, tahap cermin, akses pada bahasa, Oedipus kompleks. Tiap 
tahap dalam cerita ditandai jenis rasa kehilangan atau kekurangan.

Kehilangan pertama dalam sejarah subjek terjadi sewaktu kelahiran. Bahkan, lebih khusus lagi, pada tahap pembedaan jenis kelamin ketika berada di dalam rahim, walaupun hal ini tidak disadari dan baru disadari ketika bayi dipisahkan ibunya saat lahir. Kekurangan ini bersifat seksual dan berkaitan dengan ketidakmungkinan untuk secaa fisiologis sekaligus menjadi laki-laki dan perempuan. Pengertian mengenai keseluruhan androginus asali sangat penting bagi argument Lacan. Sang subjek didefinisikan sebagai berkekurangan karena ia dipercaya menjadi fragmen dari suatu yang lebih besar atau lebih primordial. Rasa cinta manusia satu sama lain bersumber dari kesatuan primordial ini. cinta merupakan suatu upaya pada awal mula, membuat yang dua menjadi satu dan menjembatani jurang antara satu manusia dan yang lainnya (Faruk, 2012:194).

Puisi merupakan salah satu jenis karya sastra yang digunakan oleh pengarang untuk mencurahkan perasaannya. Dalam puisi yang berjudul "Pesona Bunga yang Sirna" tergambar perasaan pengarang yaitu Erick Hidayat. Dalam puisi ini tergambar rasa sayang Erick Hidayat yang memudar kepada kekasihnya. Puisi jenis ini penulis masukkan ke dalam puisi yang bercerita tentang masalah anak manusia untuk memenuhi rasa kehilangan. Manusia saat lahir ke dunia akan merasa kehilangan, untuk memenuhi kekurangannya tersebut, manusia mencintai pasangannya. Penulis merasa tertarik untuk meneliti puisi ini untuk melihat rasa kehilangan terhadap kekasihnya dalam puisi ini yang dihubungkan dengan rasa kehilangan pada psikoanalisis Lacan, sebagaimana yang telah dipaparkan di depan.

\section{PEMBAHASAN}

Sejak lahir manusia selalu merasa kekurangan. Manusia dikenalkan dengan bahasa. Dengan bahasa, manusia mencoba memenuhi rasa kehilangan yang dirasakannya. Namun, rasa kehilangan tersebut tidak pernah terpenuhi, sebagaimana bahasa yang selalu labil yang antara penanda dan petanda selalu terjadi keterplesetan, tidak ada hubungan yang jelas antara penanda dan petanda. Berikut ini adalah contoh puisi yang di dalamnya dapat ditemukan konsep kehilangan.

PESONA BUNGA YANG SIRNA Puisi Erick Hidayat

Tangisan dari harapan dan goresan dari ingatan, kini menjelma kembali di lubuk hati.

Ya...ketika pertama kali aku 
mengagumi

kepolosan dan kemurnian dari setangkai bunga yang wangi.

Dua musim kulalui bersamanya dalam ikatan janji

saling menyayangi. Siang dan

malam pun kunikmati

seiring dengan warna-warni bumi.

Wanginya yang khas senantiasa

hiasi

hari-hariku menjadi jauh lebih

berarti.

Oh...betapa bahagianya hati ini.

Namun, seiring dengan waktu berlalu.

Rasa sayangku pada bunga itu perlahan-lahan memudar.

Segala corak dan warna yang dulu sempat kukagumi pun seketika sirna.

Karena dia. Ya...karena dia telah mengkhianati janji

dan kesetiaan yang selama ini kukemas rapi dalam hati.

Sunggguh aku tak mengerti. Betapa mudahnya ia melepas diri setelah sekian lama aku merawat dan menjaganya sepenuh hati.

Aku tak mampu menahan pedihnya luka ini.

Hingga akhirnya aku pasrah diri.

Dan berjanji

untuk meninggalkannya. Karena

tak mungkin,

tak mungkin aku menghirup

kembali

aroma bunga yang sudah tidak

wangi lagi.

Tak mungkin aku bisa menjamah

lagi

tangkai bunga yang sudah dipenuhi duri.

Mungkin suatu saat nanti dia akan mengerti,

dia akan menyesali atas durinya yang telah menyakiti.
Itupun jika ia masih memiliki hati nurani.

Dan, andai saja nanti

Aku menemukan kembali bunga yang wangi,

Kuharap corak dan warnanya jauh lebih berarti.

dan wanginya kan slalu abadi dalam hati.

Kehilangan pertama dalam sejarah subjek terjadi sewaktu kelahiran. Bahkan, lebih khusus lagi, pada tahap pembedaan jenis kelamin ketika berada di dalam rahim walaupun hal ini tidak disadari dan baru disadari ketika bayi dipisahkan ibunya saat lahir. Kekurangan ini bersifat seksual dan berkaitan dengan ketidakmungkinan untuk secara fisiologis sekaligus menjadi lakilaki dan perempuan (Faruk, 2012:194).

Puisi di atas merupakan karya yang dibuat oleh Erick Hidayat, berjenis kelamin laki-laki. Ketidak-mungkinannya untuk secara fisiologis menjadi laki-laki sekaligus perempuan membuat Erick Hidayat yang merupakan subjek dari puisi ini, mencari pasangannya yaitu wanita untuk memenuhi atau melengkapi "phallus" yang telah hilang darinya.

Puisi ini merupakan penggambaran perasaan Erick sang subjek. Setelah membaca puisi ini, teks dalam puisi ini menyiratkan perasaan hati subjek yang merasa kehilangan kekasihnya. Subjek yang merupakan laki-laki tentu memiliki kekasih yang seorang wanita. 
Penggambaran wanita dalam puisi di atas digambarkan dalam bentuk yang lain yaitu bunga. Karena bunga dapat dimetaforakan sebagai wanita.

Teori psikoanalisis Lacan menganggap alam bawah sadar manusia selalu dalam keadaan "kurang" merasa ada yang hilang sehingga tumbuh hasrat dan usaha yang terus menerus untuk menutupi kekurangan itu, menemukan kembali apa yang hilang, membuat manusia kembali lengkap, sempurna, utuh, menemukan identitasnya, menjadi dirinya sendiri. Rasa kehilangan ini dimulai dari manusia dilahirkan. Setelah lahir ke dunia, bayi selalu memiliki hasrat untuk tetap bersama ibunya yang merupakan pelengkap dari dirinya, yang mampu memenuhi apa yang kurang pada dirinya. Konsep yang demikian dapat ditemukan dalam bait pertama sebagai berikut.

\section{Tangisan dari harapan \\ dan goresan dari ingatan, kini menjelma kembali di lubuk hati. \\ Ya...ketika pertama kali aku mengagumi \\ kepolosan dan kemurnian dari setangkai bunga yang wangi.}

Tangisan merupakan metafora atau dapat diartikan sebagai saat manusia lahir ke dunia, bayi yang normal ketika akan lahir ke dunia akan menangis. Bayi di sini adalah subjek. Menangis dapat dipahami sebagai simbol bahwa subjek menangis karena merasa dipisahkan dari ibunya yang biasa bersama dengannya dalam kandungan, selama kurang lebih Sembilan bulan. Ketika lahir, subjek tersebut merepresentasikan rasa kehilangannya dengan menangis. Kemudian kata "harapan" di atas dimaknai sebagai saat di mana keinginan untuk "penuh" itu terjadi yaitu pada saat masih bersama dengan ibu di dalam kandungan. Subjek digambarkan begitu berharap pasangannya untuk dapat memenuhi apa yang kurang dalam dirinya.

Baris kedua yang berbunyi "dan goresan dari ingatan" dapat dimaknai sebagai sebuah peristiwa "goresan" yang membekas yang ada dalam ingatan. Ingatan tentang masa kecilnya yang masih bersama ibunya sebelum dipisahkan oleh ayah. Ingatan yang sebenarnya tidak sadar masih terbawa hingga saat ini.

Pada baris kelima sampai ketujuh merupakan ekspresi perasaan subjek pada saat pertama kali mengenal pujaan hatinya yang digambarkan sebagai "bunga yang wangi”. Kekasihnya digambarkan sebagai bunga yang wangi karena kepolosan dan kemurniannya. Tahap ini adalah tahap subjek "merasa" menemukan phallus yang mampu memberi keutuhan dan membuat merasa dirinya penuh. 
Dalam perjalanannya setelah memenuhi rasa kehilangannya. Subjek merasa dirinya telah terpenuhi kembali. Hal ini terlihat dalam perasaan bahagia yang dirasakan oleh diri subjek baik pada siang dan malam di setiap harinya. Hasrat subjek dapat dipenuhi dengan keberadaan kekasihnya. Kekasihnya yang merupkan "yang lain" (liyan) dari dirinya yang dirasa mampu memenuhi apa yang kurang dalam dirinya. Hal ini terlihat dalam bait kedua sebagai berikut.

\section{Dua musim kulalui bersamanya dalam ikatan janji saling menyayangi. Siang dan malam pun kunikmati seiring dengan warna-warni bumi. Wanginya yang khas senantiasa hiasi \\ hari-hariku menjadi jauh lebih berarti. Oh...betapa bahagianya hati ini.}

Namun, sebagaimana konsep Lacan yang menyatakan bahwa manusia dalam upayanya menggapai phallus, manusia menggunakan bahasa. Namun, penamaan identitas oleh bahasa tidak pernah penuh. Sifat penanda dan petanda yang labil membuat identitas itu juga tidak pernah penuh. Ia tidak pernah stabil akan tetapi selalu labil.

Imajinari merupakan istilah yang digunakan Lacan untuk menggambarkan tatanan pengalaman subjek yang didominasi oleh identifikasi dan dualitas.
Dalam skema Lacanian kecenderungan demikian tidak hanya mendahului tatanan simbolik, yang memperkenalkan subjek dengan trianggulasi Oedipal, melainkan terus ada bersamanya pada masa sesudah perolehan bahasa itu. Tahap cermin yang sudah digambarkan merupakan contoh terbaik dari imajinari ini. Ketika melihat citra dirinya di cermin, subjek mengenal dirinya, tetapi sekaligus diasingkan dari dirinya. Karena itu, subjek tersebut kemudian mempunyai suatu hubungan yang sangat mendalam yang bersifat ambivalen dengan pantulan dirinya di dalam cermin itu. Namun, karena dirinya tetap eksternal baginya, ia juga membenci citra itu. Si subjek mengalami keterombang-ambingan emosi antara emosi-emosi yang bertentangan (Faruk, 2012:194-195).

Subjek dalam puisi ini menjadikan kekasihnya sebagai cermin untuk mendefiniskan siapa dirinya. Namun, seiring berjalannya waktu, ternyata cermin yang merupakan kekasihnya tidak mampu menampilkan siapa dirinya yang sebenarnya. Keinginan untuk "menjadi penuh" memudar. Ini terlihat dalam bait ketiga sebagai berikut.

Namun, seiring dengan waktu berlalu.

Rasa sayangku pada bunga itu perlahan-lahan memudar. Segala corak dan warna yang dulu 
sempat kukagumi pun seketika

sirna.

Karena dia. Ya...karena dia telah mengkhianati janji

dan kesetiaan yang selama ini

kukemas rapi dalam hati.

Sunggguh aku tak mengerti. Betapa mudahnya ia melepas diri setelah sekian lama aku merawat dan menjaganya sepenuh hati.

Seiring berjalannya waktu ternyata subjek menyadari bahwa kekasih yang dianggapnya mampu memenuhi dan mengisi apa yang hilang dari dirinya itu tidak dapat terpenuhi. Subjek merasakan kembali rasa kehilangan dan ketidakutuhan, kehilangan phallus. Dalam bait tersebut terlihat bahwa "menghianati janji" dan "kesetiaan" yang membuat semuanya terjadi seperti penamaan identitas oleh bahasa yang tidak pernah penuh. Pertama, bahasa itu bersifat formal relaisonal sehingga identitas diri selalu berada dalam hubungan dengan yang lain. Bahasa tidak substansial ataupun referensial. Identitas yang terbantuk melalui bahasa sekaligus berlangsung melalui dialektika antara identifikasi dan rekognisi yang bisa disalahtafsirkan. Kedua, bahasa sendiri merupakan serangkaian penanda dengan kedudukan petanda yang tidak pernah stabil.

Dalam puisi tersebut, setia menurut subjek belum tentu sama dengan pengertian setia menurut orang lain. Bisa saja setia menurut subjek yang berarti tetap bersama, memadu kasih dan saling mencintai sampai ajal menjemput dapat diartikan berbeda oleh pasangannya yang mengartikan setia yaitu dengan tidak menyakiti hati pasangannya. Cara untuk tidak menyakiti hati pasangannya ini dapat dikongkretkan dengan cara meninggalkan si subjek. Hal ini terjadi karena jika pasangannya ini tetap bersama dengan subjek tersebut, dia akan menyakiti subjek baik dengan sikap maupun sifat yang dimilikinya.

Aku tak mampu menahan pedihnya luka ini.

Hingga akhirnya aku pasrah diri.

Dan berjanji untuk meninggalkannya. Karena tak mungkin, tak mungkin aku menghirup kembali aroma bunga yang sudah tidak wangi lagi.

Tak mungkin aku bisa menjamah lagi

tangkai bunga yang sudah dipenuhi duri.

Bait keempat di atas menggambarkan subjek yang menyadari bahwa usaha untuk memenuhi apa yang kurang dalam dirinya tidak dapat ditemukan dalam diri kekasihnya. Kekasihnya dirasa "tidak wangi lagi". "Tidak wangi" adalah dunia realis yang ada pada kekasihnya yang berbeda dengan dunia ideal yang dibayangkan subjek. Oleh karena itu ia memilih untuk pergi mencari 
"phallus" yang lain, yang sesuai dengan dunia ideal subjek yaitu "yang wangi”.

Kemudian di akhir puisi, pada bait terakhir, tergambar keinginan subjek yang optimis akan menemukan konsep "phallus", yang baru saja hilang dari dirinya. Phallus yang dibayangkan memiliki "hati nurani" dan digambarkan sebagai "bunga yang wangi" memiliki corak dan warna yang berarti dan selalu abadi di hati. Konsep abadi adalah konsep dunia ideal yang ada pada subjek yang berbeda dengan dunia nyata, yang terjadi saat ini, yang menunjukkan bahwa keabadiaan tidak pernah ada sebagaimana perasaan subjek yang merasa telah menemukan bagian lain dari dirinya, akan tetapi seiring berjalannya waktu, ia akan merasa kehilangan kembali.

\section{SIMPULAN}

Hasrat akhirnya menjadi sesuatu yang penting dalam kehidupan seseorang. Dalam psikoanalisis Lacan, ia berdiam dalam tataran "Yang Simbolik", di mana kehilangan atau terlepasnya sesuatu yang ideal akibat turut campurnya unsur bahasa. Yang ideal tidak dapat diraih karena berada di tataran Yang Nyata. Sehingga, dalam tataran Yang Simbolik, keinginan untuk merengkuh yang ideal tadi terbatas pada bahasa. Subjek dalam puisi tersebut memiliki hasrat yang tidak pernah bisa diraihnya dalam tataran "Yang Nyata". Dengan kata lain, hasrat yang terpenuhi dengan sempurna tidak akan pernah dapat diraih. Ia dapat dianalogikan seperti hari esok yang kita impikan saat malam hari yang tak pernah dapat diraih. Esok selalu pergi saat kita terbangun di pagi hari karena ia telah menjelma menjadi hari ini yang bukan lagi bernama esok.

\section{DAFTAR PUSTAKA}

Barry, Peter. 2010. Beginning Theory:

Pengantar Komprehensif Teori

Sastra dan Budaya (terj.

Harviyah Widiawati).

Yogyakarta: Jalasutra

Faruk. 2008. Pascastrukturalisme:

Teori, Implikasi Metodologi, dan Contoh Aplikasi.

Jakarta: Pusat Pembinaan dan Pengembangan Bahasa

Faruk. 2012. Metode Penelitian Sastra: Sebuah Penjelajahan Awal. Yogyakarta: Pustaka Pelajar

Sarup, Madan. 2011. Panduan Pengantar untuk Memahami Poststrukturalisme dan Posmodernisme. yogyakarta:Jalasutra 